\title{
Production response of multiparous Holstein cows treated with bovine somatotropin and fed diets enriched with n-3 or n-6 fatty acids ${ }^{1}$
}

\author{
M. Carriquiry, ${ }^{* 2}$ W. J. Weber, ${ }^{\star}$ C. R. Dahlen, $\dagger$ G. C. Lamb, $\ddagger^{3}$ L. H. Baumgard, $\S^{4}$ and B. A. Crooker ${ }^{* 5}$ \\ ${ }^{*}$ Department of Animal Science, University of Minnesota, St. Paul 55108-6118 \\ †Northwest Research and Outreach Center, University of Minnesota, Crookston 56716-5000 \\ $\ddagger$ North Central Research and Outreach Center, University of Minnesota, Grand Rapids 55744-3361 \\ $\S$ Department of Animal Sciences, University of Arizona, Tucson 85721-0038
}

\begin{abstract}
Multiparous cows $(\mathrm{n}=59)$ were blocked by expected calving date and previous milk yield and assigned randomly to treatments to determine the effects of bovine somatotropin (bST; Posilac, Monsanto Animal Agricultural Group, St. Louis, MO) and source of dietary fat on production responses. Diets were provided from calving and included whole, high-oil sunflower seeds [SS; $10 \%$ of dietary dry matter (DM); n-6:n-3 ratio of 4.6] as a source of linoleic acid (18:2) or a mixture of Alifet-High Energy and Alifet-Repro (AF; Alifet USA, Cincinnati, $\mathrm{OH} ; 3.5$ and $1.5 \%$ of dietary DM, respectively; $\mathrm{n}-6 / \mathrm{n}-3$ ratio of 2.6) as a source of protected n-3 fatty acids. Diets contained 181 versus $188 \mathrm{~g}$ of crude protein and 183 versus $186 \mathrm{~g}$ of acid detergent fiber $/ \mathrm{kg}$ of $\mathrm{DM}$ and 1.54 versus $1.66 \mathrm{Mcal}$ of net energy for lactation at the actual DM intake for SS versus AF, respectively. Cows received 0 or $500 \mathrm{mg}$ of bST every $10 \mathrm{~d}$ from 12 to $70 \mathrm{~d}$ in milk (DIM) and at 14-d intervals through 280 DIM. The $2 \times 2$ factorial combination of $\operatorname{diet}(\mathrm{SS}$ or AF) with or without bST administration resulted in treatments designated as SSY, SSN, AFY, and AFN, respectively. Data were analyzed as repeated measures using mixed model procedures to determine the effects of diet, bST, and their interactions. Yield of 3.5\% fat-corrected milk was not altered by diet, but was increased by $4.0 \pm$ $1.9 \mathrm{~kg} / \mathrm{d}$ from 12 to 70 DIM and by $5.1 \pm 1.2 \mathrm{~kg} / \mathrm{d}$
\end{abstract}

Received September 1, 2008.

Accepted June 19, 2009.

${ }^{1}$ This work was supported in part by a Doctoral Dissertation Research Grant from the Graduate School at the University of Minnesota, a Hueg-Harrison Fellowship, and a Sigma Delta Epsilon Fellowship all awarded to M. Carriquiry. Support for the study was also provided by the Agricultural Experiment Stations at the University of Arizona (project number ARST-136339-H-24-130) and University of Minnesota (project number 16-46).

${ }^{2}$ Current address: Facultad de Agronomía, Avda. Garzón 810, 12900 Montevideo, Uruguay.

${ }^{3}$ Current address: University of Florida-NFREC, 3925 Highway 71 , Marianna, FL 32446-8091.

${ }^{4}$ Current address: Department of Animal Science, Iowa State University, Ames, IA 50011-3150.

${ }^{5}$ Corresponding author: crook001@umn.edu from 12 to 280 DIM by bST. Treatment did not affect DM intake or energy balance (EB) nadir. There was an interaction of bST and diet on EB because AF decreased the impact of bST on overall EB and allowed AFY cows to reach a positive EB earlier than SSY cows. Gross feed efficiency adjusted for body weight change was greater for bST-treated cows (1.03 vs. 1.15 $\pm 0.03 \mathrm{~kg}$ of fat-corrected milk/Mcal of net energy for lactation). Circulating insulin-like growth factor-I concentrations were increased by bST ( 85 vs. $125 \pm 8 \mathrm{ng} /$ $\mathrm{mL}$ ). Body weight, body condition score, and backfat thickness were reduced by bST, but differences between treated and nontreated cows did not differ by 280 DIM. Results indicate cows responded to bST administration in early lactation, but the magnitude of the response was greater after 70 DIM. Source of dietary fat had a minimal effect on most production measurements, but relative to $\mathrm{SS}, \mathrm{AF}$ decreased the impact of bST on overall EB. Results support the premise that bST administration prolongs the delay in postpartum tissue replenishment.

Key words: somatotropin, n-3 fatty acid, lactation

\section{INTRODUCTION}

Increased magnitude and prolonged duration of negative energy and nutrient status during early lactation can prevent cows from reaching their true genetic potential to produce milk and can be detrimental to several physiological functions, including reproduction (Lucy and Crooker, 2001). Attempts to minimize the severity of negative energy balance (EB) have included the addition of supplemental dietary fats in early lactation. Evidence suggests that supplemental, dietary rumen-protected fat enriched in n-3 fatty acids can provide a concentrated source of energy and specific fatty acid precursors for the synthesis or inhibition of reproductive hormones and prostaglandins (Staples et al., 1998). Additional possible benefits of protected dietary fat include an increased amount of desirable lipids and a decreased ratio of n- 6 to n- 3 fatty acids in milk and tissue. These changes could improve animal 
performance, increase the functional food value of dairy products, and potentially provide beneficial effects on human health.

Commercial use of bST is limited to cows that are more than $8 \mathrm{wk}$ in lactation, in part because early studies indicated that milk yield and IGF-I response to bST were greater when cows were in positive energy and nutrient balance (Bauman, 1999) and because bST studies submitted to the US Food and Drug Administration for evaluation initiated treatment in the ninth week of lactation. Prolonged administration of bST to multiparous cows in early lactation can substantially increase circulating IGF-I concentrations and yields of milk and FCM before 70 DIM and during the entire treatment period (Carriquiry et al., 2008a). In addition, beneficial effects of bST administration on reproductive performance could include IGF-I-induced improvements in ovarian function and embryonic growth and development (Lucy, 2000).

Therefore, there is considerable potential for the combined, early lactation use of supplemental dietary fat enriched with n-3 fatty acids and administration of bST to increase production, improve reproductive performance, and enhance the functional food value of dairy products. Our objectives were to determine the effects of bST and dietary fat enriched with n-3 fatty acids on lactational performance and utilization of protein and energy.

\section{MATERIALS AND METHODS}

\section{Animals, Experimental Design, and Treatments}

Animal procedures were approved by the University of Minnesota Institutional Animal Care and Use Committee. Fifty-nine multiparous cows (29 in their second lactation and 30 in their third, fourth, or fifth lactation) were housed in tie-stall facilities at the Northwest Research and Outreach Center (Crookston, MN) of the University of Minnesota. Cows were fed a dry cow diet (Table 1) beginning $3 \mathrm{wk}$ before their expected calving date. Cows were blocked by expected calving date $(<60-\mathrm{d}$ interval within any block) and previous $305-\mathrm{d}$ mature-equivalent milk yield $(<2,900-\mathrm{kg}$ range within any block) and assigned randomly to 1 of 4 treatments in a $2 \times 2$ factorial arrangement of bST ( 0 or $500 \mathrm{mg} /$ injection; Posilac, Monsanto Animal Agricultural Group, St. Louis, MO) and source of supplemental dietary fat. Supplemental dietary fat was provided as whole sunflower seeds or as a 3.5:1.5 mixture of Alifet-High Energy and Alifet-Repro (Alifet USA, Cincinnati, OH) and represented 10 and $5 \%$ of dietary DM, respectively (Table 1). Sunflower seeds are a source of linoleic acid. Alifet-High Energy is a microcrystallized rumen-inert energy concentrate made from animal fat $(99 \%)$ rich in saturated fatty acids (57\% stearic acid; $25 \%$ palmitic acid). Alifet-Repro is a microcrystallized rumen-inert fat (flaxseed oil and fish oil) enriched with the n-3 fatty acids linolenic $(15.7 \%, 18: 3)$, eicosapentaenoic (EPA, $1.3 \%, 20: 5)$, and docosahexaenoic (DHA, 1.3\%, 22:6) acids. The n- $6 / \mathrm{n}-3$ fatty acid ratio of the sunflower seed (SS) and the Alifet (AF) diets were 4.6 and 2.6, respectively. Treatment diets (Table 1) were formulated to be isocaloric and isonitrogenous and to meet the needs of a $680-\mathrm{kg}$ Holstein cow with a peak milk yield of $55 \mathrm{~kg} / \mathrm{d}$ at 70 DIM (NRC, 2001). Treatments derived from the $2 \times 2$ factorial arrangement of $\operatorname{diet}(\mathrm{SS}, \mathrm{AF})$ and $0(\mathbf{N})$ or $500 \mathrm{mg}(\mathbf{Y})$ of bST were designated SSN, SSY, AFN, and AFY, and there were 15, 16, 15, and 13 cows/treatment, respectively.

Administration of bST was initiated on $12 \pm 3$ DIM and continued at 10-d intervals through $70 \pm 3$ DIM and at 14-d intervals thereafter through 280 DIM. Cows consumed the treatment diets from calving to at least 150 DIM. From 150 to 280 DIM, if daily milk yield decreased to less than $32 \mathrm{~kg}$ and BCS was $\geq 3.0$ units for any cow, the cow was switched to a diet that did not contain supplemental dietary fat (Table 1). For all diets, the as-fed contributions of each ingredient were adjusted weekly to account for changes in DM content of fermented feeds. The amount of feed offered each day was adjusted regularly to allow 5 to $10 \%$ refusals. Cows were offered diets as TMR once daily between 0900 and $1200 \mathrm{~h}$ and had continuous access to feed and water except during milking.

\section{Data and Sample Collection and Analyses}

Cows were milked 2 times per day at approximately 0400 and $1600 \mathrm{~h}$ and daily yields were determined from individual milk weights. Milk samples from 2 consecutive milkings were obtained weekly during the first 4 wk of lactation (WOL) and at 4-wk intervals thereafter until 280 DIM. Milk samples were preserved with potassium dichromate upon collection and were analyzed for fat, protein, and lactose by infrared analyses and for SCC by a cell counter (Stearns DHIA Laboratories, Sauk Centre, MN).

Amounts of feed offered and refused were recorded daily to determine feed intake. Samples of haylage, corn silage, and high-moisture shelled corn were collected weekly and samples of concentrates were obtained when new shipments were received. Samples were composited within 3-mo intervals or by silo if the source changed within an interval. Composites were analyzed by nearinfrared analysis (Dairy One Cooperative Inc., Ithaca, NY; Table 2). Samples of each shipment of Alifet were obtained and individual fatty acid compositions were 
Table 1. Diet ingredients for multiparous Holstein cows

\begin{tabular}{lcccc}
\hline & \multicolumn{4}{c}{ Diet $^{1}$} \\
\cline { 2 - 5 } Ingredient, \% of DM & Dry cow & SS & AF & Mid- to late lactation \\
\hline Alfalfa haylage & 37.0 & 24.0 & 27.0 & 27.0 \\
Corn silage & 37.0 & 24.0 & 27.0 & 27.0 \\
High-moisture shelled corn & 7.0 & 18.0 & 17.0 & 21.0 \\
Sugar beet pulp & 4.0 & 3.0 & 3.0 & 3.0 \\
Distillers dried grains with solubles & - & 6.0 & 6.0 & 6.0 \\
Soybean meal, 44\% & - & 12.4 & 12.4 & 10.0 \\
Sunflower seeds, whole & - & - & 3.5 & - \\
Alifet-High Energy & - & - & 1.5 & - \\
Alifet-Repro & 10.0 & - & - & - \\
Oat grain & 1.0 & 2.6 & 2.6 & 2.6 \\
Mineral and vitamin mix $^{2}$ & & & & - \\
\hline
\end{tabular}

${ }^{1}$ Diets supplemented with whole, high-oil sunflower seeds (SS) or a mixture of Alifet-High Energy and AlifetRepro (AF; Alifet USA, Cincinnati, OH).

${ }^{2}$ Mineral and vitamin mix for SS, AF, and the mid-to-late-lactation diets were identical and included calcium carbonate $(0.5 \%$ of $\mathrm{DM})$, dicalcium phosphate $(0.3 \%$ of $\mathrm{DM})$, sodium bicarbonate $(1.0 \%$ of $\mathrm{DM})$, vitamin premix (vitamin $\mathrm{A}, \mathrm{D}_{3}$, and E; Stock Aid I, Nutraserv, Cottage Grove, MN; $0.2 \%$ of $\mathrm{DM}$ ), and trace mineralized salt (Hi-Mix, Cutler-Magner Company, Duluth, MN; $0.6 \%$ of DM). The dry cow diet included calcium carbonate $(0.4 \%$ of $\mathrm{DM})$, vitamin premix (vitamin $\mathrm{A}, \mathrm{D}_{3}$, and E; Stock Aid I, Nutraserv; $0.2 \%$ of DM), and trace mineralized salt (Hi-Mix, Cutler-Magner Company; 0.6\% of DM).

determined to verify uniformity of the product. Lipids in the Alifet, SS, and each diet were extracted and fatty acid methyl esters were prepared and quantified by gas chromatography (Carriquiry et al., 2008b).

Body weight, backfat thickness (BFT), and BCS were determined at weekly intervals from -2 to $4 \mathrm{WOL}$ and at 4-wk intervals thereafter until 280 DIM. Backfat thickness between the 12th and 13th rib over the longissimus muscle was determined by ultrasound $(5.0-\mathrm{MHz}$ transducer, Aloka 500V, Aloka America, Wallingford, $\mathrm{CT}$ ). Body condition was assessed once weekly by the same individual and scored (NRC, 2001) at 0.25-unit intervals from 1.0 (emaciated) to 5.0 (obese). Cows were observed daily and maladies were treated when warranted, in accordance with established criteria and a veterinary consultation. Treatments and general health observations were recorded throughout the study.

Blood samples collected via coccygeal venipuncture were obtained between 0700 and $0900 \mathrm{~h}$ (before feeding) every Wednesday from -2 to 8 WOL and at 4 -wk intervals thereafter until 168 DIM, using Vacutainer tubes (10 mL; Becton Dickinson, Franklin Lakes, NJ) that contained sodium heparin (15 USP/mL of blood). From calving until 90 DIM, blood samples were also collected every Monday, Wednesday, and Friday in Vacutainer tubes ( $7 \mathrm{~mL}$; Becton Dickinson) that contained sodium fluoride $(2.5 \mathrm{mg} / \mathrm{mL}$ of blood $)$ and potassium oxalate (2 $\mathrm{mg} / \mathrm{mL}$ of blood). Blood was kept cold and plasma was harvested $\left(2,000 \times g\right.$ for $15 \mathrm{~min}$ at $\left.4^{\circ} \mathrm{C}\right)$ and stored at $-20^{\circ} \mathrm{C}$ until assayed.

Cows were subjected to transrectal ultrasonography of their ovaries every Monday, Wednesday, and Friday through 90 DIM and breeding was initiated after cows reached 90 DIM. These and other reproductive performance data are reported by Carriquiry et al. (2009a). Liver biopsies were obtained between 0700 and $0900 \mathrm{~h}$ (before feeding) from each cow at $-12,10,28$, and 136 DIM and used by Carriquiry et al. (2009c) to evaluate the effects of treatments and stage of lactation on alterations in hepatic gene expression. Diet and milk fatty acid profiles are reported by Carriquiry et al. (2009b).

\section{Plasma Analyses}

Concentrations of IGF-I were quantified by RIA (Weber et al., 2007) of heparinized samples collected weekly from -1 to 8 WOL and at 4 -wk intervals through 24 WOL. Samples from all 59 cows were analyzed in triplicate, and intra- and interassay coefficients of variation $(\mathbf{C V})$ were 5.4 and $11.3 \%$, respectively. Glucose and NEFA concentrations in a subset of 32 cows (8 complete blocks) were determined as described by Weber et al. (2007). Plasma glucose concentration was determined in all sodium fluoride-potassium oxalate samples collected from wk 1 to 6 and from wk 8 and 12. Heparinized samples collected at wk -1 (covariate) and wk 20 were analyzed for plasma glucose concentration. Previous work in our laboratory indicated little effect of these anticoagulants on glucose assays (B. A. Crooker, unpublished data). Intra- and interassay CV were 3.0 and $5.3 \%$, respectively. Concentrations of NEFA were determined in heparinized samples collected during -1 to $6 \mathrm{WOL}$ and during 8,12 , and 16 WOL. Intra- and interassay CV were 2.7 and $5.7 \%$, respectively. 
$\left(\mathbf{M P}_{\mathbf{P}}\right)$ was calculated as $\mathrm{MP}_{\mathrm{P}}=[(0.69 \times$ days pregnant) - 69.2]/0.33. Metabolizable protein required for lactation $\left(\mathbf{M P}_{\mathbf{L}}\right)$ was calculated as $\mathrm{MP}_{\mathrm{L}}=(\mathrm{milk}$ yield $\times$ true protein $\%) / 0.67$. Metabolizable protein required for growth $\left(\mathbf{M P}_{\mathrm{G}}\right)$ was calculated as $\mathrm{MP}_{\mathrm{G}}=$ net protein requirement for growth/efficiency of use of MP for growth. Estimated MP balance (MPB) was calculated as $\mathrm{MPB}=\mathrm{MP}$ intake $-\left(\mathrm{MP}_{\mathrm{M}}+\mathrm{MP}_{\mathrm{L}}+\right.$ $\left.\mathrm{MP}_{\mathrm{G}}+\mathrm{MP}_{\mathrm{P}}\right)$.

Fat-corrected $(3.5 \% \mathrm{FCM})$ and solids-corrected $(4 \%$ SCM) milk yields were calculated (Tyrrell and Reid, 1965). All statistical analyses were conducted with SAS Systems programs (SAS Institute Inc., Cary, NC). Univariate analyses were performed on all variables to identify outliers and inconsistencies and to verify normality of residuals. Homogeneity of variances was verified with Levene's test. Intake, EB, MPB, plasma glucose, and yields of milk, FCM, and SCM were reduced to weekly means before data analysis. Data were analyzed as a randomized block design by repeated measures using the MIXED procedure (SAS Institute Inc.) with WOL as the repeated effect and first-order autoregressive (for evenly spaced data; DMI, FCM yield, and estimated EB and MP components) or spatial power law (for unevenly spaced data; all other variables) as the covariance structure. The Kenward-Rogers procedure was used to adjust the denominator degree of freedom. The model included the effects of bST, diet, WOL, and their interactions as fixed effects and block as a random effect. Prepartum values for BW, BCS, BFT, glucose, NEFA, and IGF-I were used as covariates in their respective data analysis. Unless stated otherwise, main effect means and standard errors are reported in the text and interaction means and standard errors are reported in the tables and figures.

Daily milk yields (1 to 280 DIM) for each cow were fitted to a modified Wood's equation (Ferguson et al., 2000) and coefficients were used to generate smooth curves. The smooth curves were used to identify peak milk, days to peak milk, and rates of increase (from calving to peak DIM) and decrease (from peak to 280 DIM) in milk yield. The model included the effects of bST, diet, WOL, and their interactions as fixed effects and block as a random effect. Correlation coefficients estimated by the CORR procedure (SAS Institute Inc.) were used to describe associations between BFT and BW or BCS and among plasma IGF-I, glucose, NEFA, and EB. For all results, means were considered to differ when $P \leq 0.05$, and trends were identified when 0.05 $<P<0.10$.

\section{RESULTS}

General health was typical of high-producing cows and there was no evidence of any effect of treatment on animal health. Episodes of ketosis $(\mathrm{n}=9)$, milk fever ( $\mathrm{n}$ $=5)$, and mastitis $(\mathrm{n}=24)$ occurred more frequently than other health problems ( $<2$ episodes per ailment). Milk yield and DMI were not affected by liver biopsies (data not presented). Although bST treatment was not initiated until $12 \pm 3$ DIM, data were evaluated from calving because fat source differed from calving and the results and interpretation did not differ whether data from the first 12 DIM were included or excluded. Most cows (78\%) continued to produce large quantities of milk ( $>32 \mathrm{~kg} / \mathrm{d}$ ) throughout the study and were not shifted to the mid-to-late-lactation diet. Milk yield from only 13 cows decreased sufficiently to warrant a shift to the mid-to-late-lactation diet before 280 DIM. This diet shift occurred for 4 SSN cows between 194 and 239 DIM $($ mean $=213, \mathrm{SD}=19$ DIM $), 3$ SSY cows between 267 and $276 \mathrm{DIM}$ (mean $=272, \mathrm{SD}=5 \mathrm{DIM})$, and 6 AFN cows between 190 and 271 DIM (mean $=243$, SD $=32$ DIM). No AFY cows were switched to the midto-late-lactation diet before 280 DIM. Total cow days during which cows consumed the mid-to-late-lactation diet represented $<5 \%$ of the total cow days per treatment for any of the treatments. Results and interpretation did not differ whether data collected from these 13 cows after the diet switch were included or excluded from the analyses, so the data were included.

\section{Dietary Treatments}

Diets SS and AF were formulated to meet the needs of a $680-\mathrm{kg}$ Holstein cow with a milk yield of $55 \mathrm{~kg} / \mathrm{d}$ at 70 DIM and a predicted peak DMI of $29.9 \mathrm{~kg} / \mathrm{d}(4.7 \times$ maintenance). When these production measures and the results of ingredient analyses were used to predict $\mathrm{NE}_{\mathrm{L}}$ content, SS and $\mathrm{AF}$ contained similar amounts of $\mathrm{NE}_{\mathrm{L}}$ (1.68 and $1.71 \mathrm{Mcal} / \mathrm{kg}$, respectively). As expected, production measures for individual cows varied around these formulation standards and resulted in $\mathrm{NE}_{\mathrm{L}-\mathrm{Actual}} \mathrm{DMI}$ values of 1.54 and $1.66 \mathrm{Mcal} / \mathrm{kg}$ for $\mathrm{SS}$ and AF, respectively (Table 2). This difference of 0.12 Mcal/kg represented $7.8 \%$ of the value for SS. Nutrient content of the SS and AF diets differed by less than $4 \%$ for all major components except ether extract and ash, for which differences represented 11.7 and 5.5\% of the value for $\mathrm{AF}$, respectively. The AF diet was the only diet to provide 18:1-trans fatty acid, and a greater proportion of cis polyunsaturated fatty acids (PUFA) was present in the SS diet. Concentrations of EPA and DHA in the AF diet were $2.2(175 \%)$ and $1.6(400 \%)$ $\mathrm{mg} / \mathrm{g}$ greater and the $\mathrm{n}-6 / \mathrm{n}-3$ ratio was reduced by $42 \%$ relative to the SS diet (Table 2).

\section{Milk Yield and Composition}

Yields of milk, FCM, and SCM during the first 280 DIM were increased $(P<0.002)$ by bST administration 
Table 3. Effects of dietary fat enriched with n-3 fatty acids, ${ }^{1}$ bST, and week of lactation on production variables of multiparous Holstein cows during the first 280 DIM

\begin{tabular}{|c|c|c|c|c|c|c|c|c|c|c|c|c|}
\hline \multirow[b]{2}{*}{ Variable } & \multicolumn{4}{|c|}{ Treatment $^{2}$} & \multirow[b]{2}{*}{$\mathrm{SE}$} & \multicolumn{7}{|c|}{$P$-value ${ }^{3}$} \\
\hline & SSN & SSY & $\mathrm{AFN}$ & $\mathrm{AFY}$ & & $\mathrm{D}$ & B & $\mathrm{D} \times \mathrm{B}$ & $\mathrm{W}$ & $\mathrm{D} \times \mathrm{W}$ & $\mathrm{B} \times \mathrm{W}$ & $\begin{array}{c}\mathrm{D} \times \\
\mathrm{B} \times \mathrm{W}\end{array}$ \\
\hline $3.5 \% \mathrm{FCM}^{4} \mathrm{~kg} / \mathrm{d}$ & 41.7 & 48.0 & 43.3 & 47.2 & 1.2 & 0.695 & 0.001 & 0.227 & 0.001 & 0.433 & 0.019 & 0.196 \\
\hline $4.0 \% \mathrm{SCM}^{4}{ }^{4} \mathrm{~kg} / \mathrm{d}$ & 38.4 & 44.1 & 39.5 & 43.0 & 1.0 & 0.994 & 0.001 & 0.201 & 0.001 & 0.438 & 0.003 & 0.122 \\
\hline Fat, kg/d & 1.58 & 1.80 & 1.68 & 1.80 & 0.07 & 0.377 & 0.008 & 0.378 & 0.001 & 0.460 & 0.053 & 0.628 \\
\hline Fat, $\%$ & 3.89 & 4.22 & 4.12 & 4.19 & 0.14 & 0.469 & 0.146 & 0.355 & 0.001 & 0.146 & 0.499 & 0.893 \\
\hline Protein, \% & 3.14 & 3.20 & 3.13 & 3.08 & 0.03 & 0.026 & 0.782 & 0.087 & 0.001 & 0.105 & 0.242 & 0.283 \\
\hline Lactose, \% & 4.91 & 4.96 & 4.89 & 4.94 & 0.03 & 0.382 & 0.011 & 0.928 & 0.001 & 0.672 & 0.047 & 0.967 \\
\hline SCC, $\log _{10}$ & 5.03 & 5.22 & 5.00 & 4.90 & 0.13 & 0.199 & 0.774 & 0.233 & 0.001 & 0.731 & 0.799 & 0.949 \\
\hline \multicolumn{13}{|l|}{ Milk plot characteristic ${ }^{5}$} \\
\hline Peak milk yield, d & 56.6 & 69.3 & 53.1 & 74.7 & 5.5 & 0.864 & 0.003 & 0.411 & & & & \\
\hline Milk yield at peak, $\mathrm{kg}$ & 48.5 & 51.6 & 49.3 & 50.6 & 1.3 & 0.948 & 0.068 & 0.423 & & & & \\
\hline
\end{tabular}

${ }^{1}$ Cows were fed diets that contained whole, high-oil sunflower seeds (SS; n-6/n-3 fatty acids = 4.6) or a mixture of Alifet-High Energy and AlifetRepro (AF; Alifet USA, Cincinnati, OH; n-6/n-3 fatty acids = 2.6) through at least 190 DIM.

${ }^{2}$ Least squares means for treatments derived from a $2 \times 2$ combination of supplemental fat source (SS, AF) beginning at calving and with 0 (SSN, AFN) or 500 (SSY, AFY) mg of bST administered every $10 \mathrm{~d}$ from 12 to 70 DIM and at 14-d intervals thereafter. Number of cows per treatment $=15,16,15$, and 13 for SSN, SSY, AFN, and AFY, respectively.

${ }^{3} \mathrm{D}=$ diet; $\mathrm{B}=\mathrm{bST} ; \mathrm{W}=$ week of lactation.

${ }^{4} 3.5 \% \mathrm{FCM}=0.4324 \times$ milk yield $(\mathrm{kg})+16.218 \times$ fat yield $(\mathrm{kg})$, and $4.0 \% \mathrm{SCM}=12.24 \times$ fat yield $(\mathrm{kg})+7.10 \times \mathrm{protein}$ yield $(\mathrm{kg})+6.35$ $\times$ lactose yield $(\mathrm{kg})-0.0345 \times$ milk yield $(\mathrm{kg})$ according to Tyrrell and Reid (1965)

${ }^{5}$ Calculated from smooth curves generated for each cow using daily milk yields (1 to 280 DIM) and a modified Wood's equation (daily milk yield $=\mathrm{A} \times \mathrm{DIM}^{\mathrm{b}} \times \mathrm{e}^{\mathrm{c} \times \mathrm{DIM}}$, where A, b, and c are parity-based parameter estimates) according to Ferguson et al. (2000).

$(3.1 \pm 1.0,5.1 \pm 1.2$, and $4.7 \pm 1.0 \mathrm{~kg} / \mathrm{d}$, respectively $)$ and were altered $(P<0.001)$ by WOL and the interaction $(P<0.02)$ of bST and WOL (Table 3, Figure $1 \mathrm{~A})$, but were not altered $(P>0.6)$ by supplemental dietary fat. There was a trend for an interaction $(P=0.051)$ of bST, diet, and WOL on yield of milk, but not on FCM or SCM. After 3, 3, and 6 wk of bST treatment $(5,5$, and 8 WOL $)$, yields of FCM, SCM, and milk had increased $(P<0.05)$ by $4.6 \pm 1.6,3.5 \pm 1.4$, and $3.4 \pm$ $1.1 \mathrm{~kg} / \mathrm{d}$, respectively. By 70 DIM, bST had increased yields of FCM, SCM, and milk by $4.0 \pm 1.9,2.5 \pm 1.1$, and $0.8 \pm 0.9 \mathrm{~kg} / \mathrm{d}$, respectively. Peak milk occurred $17 \mathrm{~d}(54.9$ vs. $72.0 \pm 3.9 \mathrm{DIM})$ later $(P=0.003)$ and tended $(P=0.068)$ to be greater $(48.9$ vs. $51.1 \pm 1.0$ $\mathrm{kg}$ ) in bST-treated cows. The rate of increase from calving to peak yield $(0.26 \pm 0.02 \mathrm{~kg} / \mathrm{d})$ and the rate of decrease from peak yield to 280 DIM $(-0.09 \pm 0.01$ $\mathrm{kg} / \mathrm{d})$ were not affected $(P>0.30)$ by bST (Table 3 ).

Percentage of milk fat was similar $(P>0.35)$ among treatments $(4.11 \pm 0.14 \%)$, but percentage of milk protein was reduced $(P=0.026)$ in cows fed AF (3.17 vs. $3.10 \pm 0.03 \%)$. Percentage of milk lactose was greater $(P=0.011)$ for cows treated with bST (4.90 vs. 4.95 $\pm 0.02 \%$; Table 3 ). Percentages of milk fat and protein were decreased $(P<0.001)$ and percentage of milk lactose was increased $(P<0.001)$ with the increase in milk yield in early lactation. In contrast, as milk yield decreased later in lactation, percentages of milk fat and protein increased $(P<0.001)$ and percentage of milk lactose decreased $(P<0.001)$. There was a bST $\times$ WOL interaction $(P=0.047)$ for percentage of milk lactose because administration of bST increased lactose concentration between 16 and 32 WOL. Yields of milk fat (1.63 vs. $1.80 \pm 0.05 \mathrm{~kg} / \mathrm{d})$, protein (1.27 vs. 1.35 $\pm 0.02 \mathrm{~kg} / \mathrm{d})$, and lactose (2.01 vs. $2.15 \pm 0.04 \mathrm{~kg} / \mathrm{d}$, Table 3$)$ were increased $(P<0.008)$ by bST but did not differ between diets $(P>0.19)$. Consistent with the differences in milk yield elicited by bST, there were interactions of bST with WOL on yields of protein $(P$ $<0.001)$ and lactose $(P=0.006)$ and a trend $(P=$ $0.053)$ for this interaction on yield of fat. Milk SCC averaged less than 200,000 cells $/ \mathrm{mL}$ and did not differ among treatments $(P>0.20)$.

\section{DMI and Estimated Energy and MP Balance}

Dry matter intake increased $(P<0.001)$ after calving, peaked at $14 \mathrm{WOL}(28.3 \pm 0.72 \mathrm{~kg}$ of DM/d $)$, and remained relatively constant for $20 \mathrm{wk}$ before beginning to decrease slowly (Table 4, Figure 1B). There was an overall negative estimated $\mathrm{EB}(-0.35$ vs. $1.07 \pm 0.53$ Mcal of $\left.\mathrm{NE}_{\mathrm{L}} / \mathrm{d} ; P=0.027\right)$ for cows fed SS rather than 

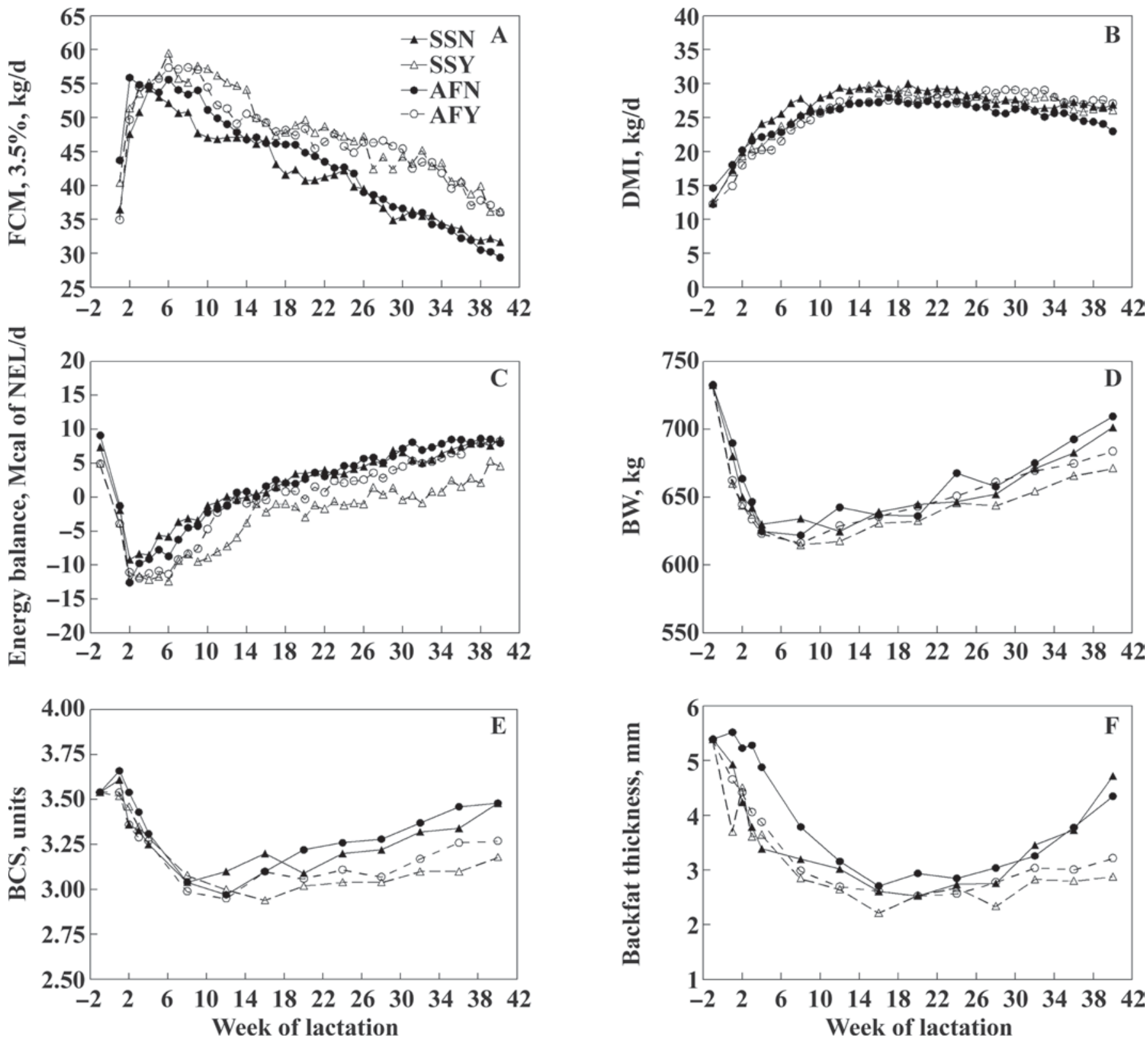

Figure 1. Effect of dietary fat enriched with n-3 fatty acids and bST administration on FCM (A), DMI (B), energy balance (C), BW (D), BCS (E), and backfat thickness (F) of multiparous Holstein cows. Diets contained whole, high-oil sunflower seeds (SS; n-6/n-3 fatty acids $=4.6)$ or a mixture of Alifet-High Energy and Alifet-Repro (AF; Alifet USA, Cincinnati, OH; n-6/n-3 fatty acids = 2.6) and were fed from calving. Cows received 0 (SSN, AFN) or 500 (SSY, AFY) mg of bST every $10 \mathrm{~d}$ from 12 to 70 DIM and at 14-d intervals thereafter. Data are from 15 , 16, 15, and $13 \mathrm{SSN}, \mathrm{SSY}, \mathrm{AFN}$, and AFY cows, respectively. Standard errors of the mean averaged $2.2 \mathrm{~kg} / \mathrm{d}, 1.3 \mathrm{~kg} / \mathrm{d}, 1.4 \mathrm{Mcal}$ of NE $/ \mathrm{d}, 12.5$ $\mathrm{kg}, 0.09$ units, and $0.39 \mathrm{~mm}$ for FCM, DMI, energy balance, BW, BCS, and backfat thickness, respectively.

AF. Administration of bST decreased $(P<0.001)$ the estimated EB during the first 280 DIM (2.02 vs. -1.31 $\pm 0.53 \mathrm{Mcal}$ of $\left.\mathrm{NE}_{\mathrm{L}} / \mathrm{d}\right)$, and cows treated with bST had greater $(P<0.001)$ milk energy output and similar energy intake compared with non-bST-treated cows (Table 4, Figure 1C). There was an interaction of diet and $\operatorname{bST}(P=0.024)$ on EB because AF improved EB in the bST-treated cows (Table 4). Week of lactation affected $(P<0.001)$ EB because EB decreased after calving, reached a nadir, and increased thereafter. The postpartum EB nadir occurred at $2 \pm 0.5 \mathrm{WOL}$ and was similar for all treatments $(-11.22 \pm 0.75 \mathrm{Mcal} / \mathrm{d})$. Although the EB of untreated cows began to increase soon after the EB nadir, the EB of bST-treated cows did not begin to increase until approximately 6 WOL. A positive EB occurred at 10 WOL for the SSN, AFN, and AFY cows and at 15 WOL for the SSY cows. Gross efficiency of feed utilization corrected for BW loss or 
Table 4. Effect of dietary fat enriched with n-3 fatty acids, ${ }^{1}$ bST, and week of lactation on DMI, BW, BCS, backfat thickness, estimated energy and MP balances, and feed efficiency of multiparous Holstein cows during the first 280 DIM

\begin{tabular}{|c|c|c|c|c|c|c|c|c|c|c|c|c|}
\hline \multirow[b]{2}{*}{ Variable } & \multicolumn{4}{|c|}{ Treatment $^{2}$} & \multirow[b]{2}{*}{$\mathrm{SE}$} & \multicolumn{7}{|c|}{$P$-value ${ }^{3}$} \\
\hline & SSN & SSY & $\mathrm{AFN}$ & $\mathrm{AFY}$ & & $\mathrm{D}$ & $\mathrm{B}$ & $\mathrm{D} \times \mathrm{B}$ & W & $\mathrm{D} \times \mathrm{W}$ & $\mathrm{B} \times \mathrm{W}$ & $\begin{array}{c}\mathrm{D} \times \\
\mathrm{B} \times \mathrm{W}\end{array}$ \\
\hline DMI, $\mathrm{kg} / \mathrm{d}$ & 26.8 & 26.1 & 25.1 & 25.8 & 0.9 & 0.223 & 0.992 & 0.384 & 0.001 & 0.640 & 0.192 & 0.113 \\
\hline $\mathrm{BW}, \mathrm{kg}$ & 653 & 641 & 659 & 648 & 9.0 & 0.180 & 0.001 & 0.868 & 0.001 & 0.764 & 0.481 & 0.856 \\
\hline BCS, units & 3.27 & 3.16 & 3.32 & 3.19 & 0.07 & 0.254 & 0.001 & 0.721 & 0.001 & 0.784 & 0.397 & 0.109 \\
\hline Backfat, mm & 3.47 & 3.02 & 3.91 & 3.27 & 0.20 & 0.056 & 0.003 & 0.586 & 0.001 & 0.507 & 0.037 & 0.406 \\
\hline \multicolumn{13}{|l|}{ Estimated energy balance ${ }^{4}$} \\
\hline Maintenance, & 10.4 & 10.3 & 10.5 & 10.1 & 0.2 & 0.984 & 0.147 & 0.455 & 0.001 & 0.385 & 0.676 & 0.529 \\
\hline \multicolumn{13}{|l|}{ Mcal of $\mathrm{NE}_{\mathrm{L}} / \mathrm{d}$} \\
\hline Milk, Mcal of $\mathrm{NE}_{\mathrm{L}} / \mathrm{d}$ & 28.0 & 32.0 & 28.9 & 31.4 & 0.7 & 0.945 & 0.001 & 0.170 & 0.001 & 0.329 & 0.001 & 0.378 \\
\hline Balance, Mcal of $\mathrm{NE}_{\mathrm{L}} / \mathrm{d}$ & $2.04^{\mathrm{a}}$ & $-2.75^{\mathrm{c}}$ & $2.00^{\mathrm{a}}$ & $0.13^{\mathrm{b}}$ & 0.69 & 0.027 & 0.001 & 0.024 & 0.001 & 0.652 & 0.502 & 0.762 \\
\hline \multicolumn{13}{|l|}{ Gross feed efficiency } \\
\hline $\begin{array}{l}\text { Apparent, } \mathrm{kg} \text { of } \mathrm{FCM} / \\
\text { Mcal of } \mathrm{NE}_{\mathrm{L}}\end{array}$ & 1.03 & 1.20 & 1.05 & 1.14 & 0.03 & 0.438 & 0.001 & 0.204 & & & & \\
\hline \multicolumn{13}{|l|}{ Estimated MP balance ${ }^{4}$} \\
\hline Endogenous, $\mathrm{g}$ of $\mathrm{MP} / \mathrm{d}$ & 127 & 124 & 119 & 123 & 4 & 0.223 & 0.992 & 0.382 & 0.001 & 0.640 & 0.192 & 0.113 \\
\hline Maintenance, $\mathrm{g}$ of $\mathrm{MP} / \mathrm{d}$ & 1,112 & 1,085 & 1,049 & 1,074 & 33 & 0.225 & 0.965 & 0.395 & 0.001 & 0.769 & 0.241 & 0.491 \\
\hline Milk, $g$ of MP/d & 1,982 & 2,180 & 1,967 & 2,091 & 850 & 0.053 & 0.001 & 0.173 & 0.001 & 0.324 & 0.001 & 0.010 \\
\hline Balance, $\mathrm{g}$ of $\mathrm{MP} / \mathrm{d}$ & $125^{\mathrm{a}}$ & $-119^{\mathrm{b}}$ & $-28^{\mathrm{b}}$ & $-87^{\mathrm{b}}$ & 47 & 0.140 & 0.001 & 0.027 & 0.001 & 0.652 & 0.202 & 0.762 \\
\hline
\end{tabular}

${ }^{\mathrm{a}-\mathrm{c}}$ Means with different superscripts within a row differ, $P<0.05$.

${ }^{1}$ Cows were fed diets that contained whole, high-oil sunflower seeds (SS; n-6/n-3 fatty acids = 4.6) or a mixture of Alifet-High Energy and AlifetRepro (AF; Alifet USA, Cincinnati, OH; n-6/n-3 fatty acids = 2.6) through at least 190 DIM.

${ }^{2}$ Least squares means for treatments derived from a $2 \times 2$ combination of supplemental fat source (SS, AF) beginning at calving and with 0 (SSN, AFN) or 500 (SSY, AFY) mg of bST administered every 10 d from 12 to 70 DIM and at 14-d intervals thereafter. Number of cows per treatment $=15,16,15$, and 13 for SSN, SSY, AFN, and AFY, respectively.

${ }^{3} \mathrm{D}=$ diet; $\mathrm{B}=\mathrm{bST} ; \mathrm{W}=$ week of lactation

${ }^{4}$ Intake energy, required energy for maintenance, milk, growth (not presented), and pregnancy (not presented), and MP supply and requirement values were calculated according to NRC (2001).

${ }^{5}$ Adjusted for BW gain or loss according to NRC (2001) equations.

gain during the first 280 DIM (Table 4) was improved $(P<0.001)$ with the administration of bST $(1.03$ vs. $1.15 \pm 0.03 \mathrm{~kg}$ of $\mathrm{FCM} / \mathrm{Mcal}$ of $\mathrm{NE}_{\mathrm{L}}$ intake). During the first 280 DIM, adjusted gross efficiencies for SS and $\mathrm{AF}$ were 1.12 and $1.09 \pm 0.03 \mathrm{~kg}$ of $\mathrm{FCM} /$ Mcal of $\mathrm{NE}_{\mathrm{L}}$ intake, respectively.

Metabolizable protein balance decreased $(P<0.001)$ with administration of bST (48.4 vs. $-102.7 \pm 37.2 \mathrm{~g}$ of $\mathrm{MP} / \mathrm{d}$ ) because cows treated with bST had a greater $(P<0.001)$ output of MP in milk but had a similar MP intake as non-bST-treated cows (Table 4). Cows fed AF consumed less $(P=0.036) \mathrm{MP}$ and tended $(P=0.053)$ to have a reduced output of MP in milk compared with cows fed SS. Metabolizable protein balance did not differ $(P=0.14)$ between SS and AF (3.2 vs. $-57.6 \pm 37.2$ $\mathrm{g}$ of $\mathrm{MP} / \mathrm{d}$, respectively) and MPB did not differ $(P>$ $0.14)$ from zero. There was an interaction of diet with $\operatorname{bST}(P=0.027)$ on MPB because MPB was greater for SSN than for SSY, AFN, and AFY (Table 4). Similar to $\mathrm{EB}$, there was an effect of WOL $(P<0.001)$ on MPB because MPB decreased after calving, reached a nadir at $2 \mathrm{WOL}$, and increased thereafter. Postpartum MPB nadir $(-595.5 \pm 47.1 \mathrm{~g}$ of $\mathrm{MP} / \mathrm{d})$ did not differ $(P>0.05)$ among treatments.

\section{Body Measurements}

Cow BW and BCS during the first 40 WOL (Table 4, Figure 1D and 1E) did not differ between diets $(P>$ $0.18)$ but were reduced $(P<0.01)$ by bST $(656$ vs. 645 $\pm 9 \mathrm{~kg} / \mathrm{d}$ of BW and $3.30 \mathrm{vs} .3 .18 \pm 0.06$ units of BCS). There was an effect of WOL $(P<0.001)$ because BW and BCS decreased after calving, reached a nadir at 8 and 12 WOL, respectively, and increased thereafter. There was no effect $(P>0.10)$ of bST or diet on BW or BCS before nadir (Figure 1). At nadir, cows had lost $51 \pm 10 \mathrm{~kg}$ of BW and $0.55 \pm 0.1$ units of BCS. Cows returned to their calving BW by 32 WOL but had not attained their calving BCS by 40 WOL. At 40 WOL, cows not treated with bST had approximately 0.25 units more BCS than bST-treated cows.

Cow BFT during the first 40 WOL (Table 4) tended to increase $(P=0.056)$ for cows fed the AF diet $(3.25$ 
Table 5. Effect of dietary fat enriched with n-3 fatty acids, ${ }^{1}$ bST, and week of lactation on plasma concentrations of IGF-I, NEFA, and glucose in multiparous Holstein cows

\begin{tabular}{|c|c|c|c|c|c|c|c|c|c|c|c|c|}
\hline \multirow[b]{2}{*}{ Variable } & \multicolumn{4}{|c|}{ Treatment $^{2}$} & \multirow[b]{2}{*}{$\mathrm{SE}$} & \multicolumn{7}{|c|}{$P$-value ${ }^{3}$} \\
\hline & SSN & SSY & $\mathrm{AFN}$ & $\mathrm{AFY}$ & & $\mathrm{D}$ & B & $\mathrm{D} \times \mathrm{B}$ & $\mathrm{W}$ & $\mathrm{D} \times \mathrm{W}$ & $\mathrm{B} \times \mathrm{W}$ & $\begin{array}{c}\mathrm{D} \times \\
\mathrm{B} \times \mathrm{W}\end{array}$ \\
\hline $\mathrm{NEFA}^{5} \mu \mathrm{Eq} / \mathrm{L}$ & 356.9 & 415.2 & 427.9 & 450.1 & 53.0 & 0.153 & 0.276 & 0.625 & 0.001 & 0.582 & 0.145 & 0.965 \\
\hline Glucose ${ }^{5} \mathrm{mg} / \mathrm{dL}$ & 56.4 & 57.9 & 57.2 & 56.7 & 2.4 & 0.943 & 0.841 & 0.666 & 0.001 & 0.030 & 0.050 & 0.800 \\
\hline
\end{tabular}

${ }^{1}$ Cows were fed diets that contained whole, high-oil sunflower seeds (SS; n-6/n-3 fatty acids = 4.6) or a mixture of Alifet-High Energy and AlifetRepro (AF; Alifet USA, Cincinnati, OH; n-6/n-3 fatty acids = 2.6) through at least 190 DIM.

${ }^{2}$ Data represent least squares means for treatments derived from a $2 \times 2$ combination of supplemental fat source (SS, AF) beginning at calving and with 0 (SSN, AFN) or 500 (SSY, AFY) mg of bST administered every $10 \mathrm{~d}$ from 12 to $70 \mathrm{DIM}$ and at 14-d intervals thereafter.

${ }^{3} \mathrm{D}=$ diet; $\mathrm{B}=\mathrm{bST} ; \mathrm{W}=$ week of lactation.

${ }^{4}$ Data obtained from the complete set of cows (15, 16, 15, and 13 for SSN, SSY, AFN, and AFY, respectively) during the first 168 DIM.

${ }^{5}$ Data obtained from a subset of 32 cows ( 8 complete blocks) during the first 112 (NEFA) or 140 (glucose) DIM.

vs. $3.10 \pm 0.15 \mathrm{~mm})$ and decreased $(P=0.003)$ with administration of bST (3.69 vs. $3.14 \pm 0.15 \mathrm{~mm})$. There was an effect of WOL $(P<0.001)$ on BFT: BFT decreased after calving, reached a minimum BFT at 16 WOL, and increased thereafter. There was no effect $(P$ $>0.10$ ) of treatment on BFT nadir, and cows lost 2.85 $\pm 0.4 \mathrm{~mm}$ of BFT (Figure 1F). There was an interaction of bST with WOL on BFT $(P=0.037)$ because BFT was less after 32 WOL in cows treated with bST. Neither treated nor nontreated cows attained their calving BFT by 40 WOL. Backfat thickness was correlated positively with BCS $(\mathrm{r}=0.56, P<0.001, \mathrm{n}=746)$ and with BW $(\mathrm{r}=0.41, P<0.001, \mathrm{n}=742)$.

\section{Blood Components}

Plasma IGF-I concentrations for the first 168 DIM (Table 5) were greater for cows fed AF than SS (98.6 vs. $112.2 \pm 6.7 \mathrm{ng} / \mathrm{mL} ; P=0.024)$ and for cows treated with bST (85.7 vs. $125.1 \pm 6.7 \mathrm{ng} / \mathrm{mL} ; P<0.001)$. Plasma IGF-I (Figure 2A) changed with WOL $(P<$ 0.001 ) because it decreased at calving, remained low for an interval, and returned to precalving concentrations as lactation progressed. There was an interaction of bST with WOL $(P<0.001)$ because bST increased plasma IGF-I by 5 WOL and allowed cows to reach precalving concentrations of IGF-I between 8 and 12 WOL. In contrast, cows that were not treated with bST had not attained precalving plasma IGF-I concentrations by 24 WOL. The results and interpretation did not differ whether IGF-I data from all 59 cows or from the subset of 32 cows ( 8 complete blocks) were evaluated.

Plasma NEFA concentrations for the first 112 DIM did not differ $(P>0.153)$ among treatments (Table 5, Figure 2B) and averaged $412.5 \pm 53.0 \mu \mathrm{Eq} / \mathrm{L}$. Plasma NEFA increased after calving, peaked at $4 \mathrm{WOL}$, and returned to precalving levels by 8 WOL. Plasma glucose concentrations during the first 140 DIM (Table
$5)$ were similar $(P>0.66)$ among treatments and averaged $57.1 \pm 2.4 \mathrm{mg} / \mathrm{dL}$. There was an interaction of bST and WOL $(P=0.050)$ because cows treated with bST had greater $(P=0.011)$ plasma glucose at 20 WOL (Figure 2C). There was an interaction of diet and WOL $(P=0.030)$ because cows fed AF tended to have greater plasma glucose early in lactation and cows fed SS tended to have greater plasma glucose after 8 WOL. Negative correlations were detected between plasma concentrations of NEFA and glucose $(\mathrm{r}=-0.25 ; P<$ $0.001 ; \mathrm{n}=278)$ and IGF-I $(\mathrm{r}=-0.18 ; P=0.001 ; \mathrm{n}$ $=310)$, and between NEFA and EB $(\mathrm{r}=-0.35 ; P<$ $0.001 ; \mathrm{n}=299$ ). Positive correlations were detected between plasma IGF-I and glucose $(\mathrm{r}=0.40 ; P<0.001$; $\mathrm{n}=309)$ concentrations. Plasma IGF-I $(\mathrm{r}=0.26 ; P<$ $0.001 ; \mathrm{n}=390)$ and glucose $(\mathrm{r}=0.47 ; P<0.001 ; \mathrm{n}=$ 300) were correlated positively with EB.

\section{DISCUSSION}

\section{Milk Yield and Composition}

Initiation of bST administration to high-producing cows at $12 \pm 3$ DIM increased FCM yield by $5.1 \mathrm{~kg} / \mathrm{d}$ through 280 DIM. Cows were in negative EB at the initiation of bST administration, but bST increased the yield of milk by $0.8 \mathrm{~kg} / \mathrm{d}$ and FCM by $4.0 \mathrm{~kg} / \mathrm{d}$ during the first 70 DIM. Although the milk response to bST in early lactation can be less than when initiated after 60 DIM, Carriquiry et al. (2008a) reported that milk and FCM responses can be similar to those obtained when treatment was initiated after peak milk yield or after 60 DIM. Milk and FCM responses to bST are usually quite rapid (Bauman, 1999) and were significant in our study after 3 wk of treatment. In contrast to previous reports (Bauman, 1999), bST did not increase persistency of milk yield in our study. Our results are consistent with the report of Moallem et al. (2000) that peak milk yield was greater and occurred later in lactation and that 

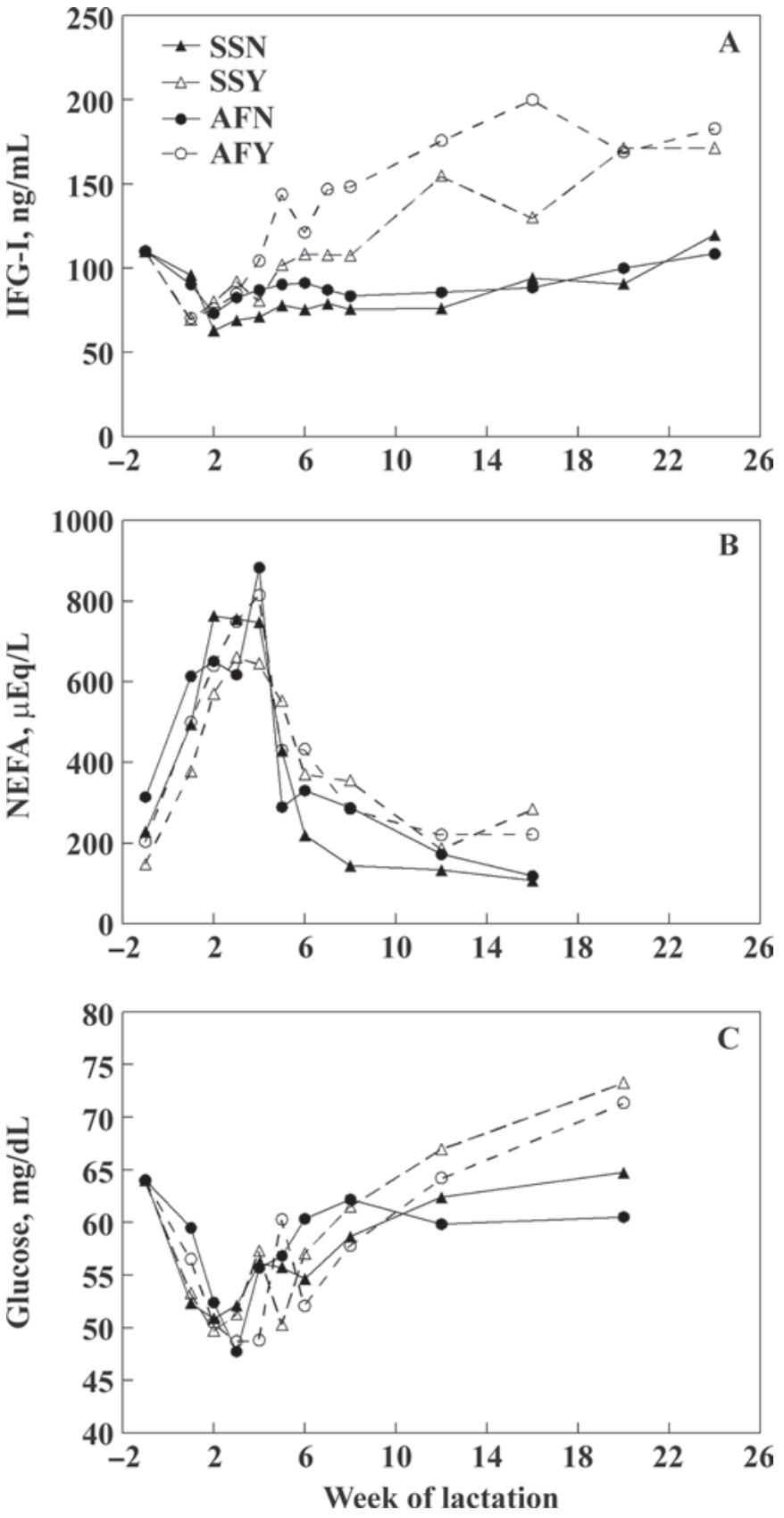

Figure 2. Effect of dietary fat enriched with n-3 fatty acids and bST administration on plasma IGF-I (A), NEFA (B), and glucose (C) in multiparous Holstein cows. Diets contained whole, high-oil sunflower seeds (SS; n-6/n-3 fatty acids $=4.6$ ) or a mixture of Alifet-High Energy and Alifet-Repro (AF; Alifet USA, Cincinnati, OH; n-6/n-3 fatty acids $=2.6$ ) and were fed from calving. Cows received 0 (SSN, AFN) or 500 (SSY, AFY) mg of bST every $10 \mathrm{~d}$ from 12 to 70 DIM and at 14-d intervals thereafter. The NEFA and glucose data are from 32 cows (8 complete blocks), and the IGF-I data are from $15,16,15$, and 13 SSN, SSY, AFN, and AFY cows, respectively. Standard errors of the mean averaged $13.6 \mathrm{ng} / \mathrm{mL}, 116 \mu \mathrm{Eq} / \mathrm{L}$, and $3.76 \mathrm{mg} / \mathrm{dL}$ for IGF-I, NEFA, and glucose, respectively. total milk yield remained greater throughout the entire interval of bST administration.

Increased milk and FCM yields in early lactation have occurred when bST-treated cows have been fed typical moderate, high-energy, high-protein, or highenergy and high-protein diets (Moallem et al., 1997). There was no interaction of bST and diet and no 3-way interaction of treatments with WOL on FCM yield in our study. This lack of a diet $\times$ bST effect is similar to what Bauman (1999) observed when bST administration was initiated later in lactation. These results are consistent with the premise that bST administration causes normal physiological alterations that enable the cow to produce more milk (Bauman, 1999) without the need for specific modifications of nutrient or energy content of the diet (Vicini et al., 1995). Our diets were formulated to have similar energy and nutrient contents and to differ primarily in source of dietary fat. Although animal characteristics $(\mathrm{DMI})$ resulted in a greater $\mathrm{NE}_{\mathrm{L}}$ discount and a reduced $\mathrm{NE}_{\mathrm{L}}$ content for $\mathrm{SS}$, the difference in $\mathrm{NE}_{\mathrm{L}}$ content of $\mathrm{SS}$ and $\mathrm{AF}$ adjusted for actual DMI was small $(0.12 \mathrm{Mcal} / \mathrm{kg})$.

Source of fat affected milk fatty acid profiles (Carriquiry et al., 2009b) but had no effect on any milk production variables, except for a decrease in milk protein percentage when cows consumed the AF diet. In agreement with reports of long-term administration of bST or administration of bST when cows remained in positive EB (Bauman, 1999; Dohoo et al., 2003), overall milk fat and protein content were not altered by bST. Milk fat percentages similar to those reported in the current study were observed when cows were fed whole flax or sunflower seeds, or when these seeds were treated with formaldehyde (Petit, 2003). Decreased milk protein percentage occurs frequently, but not always (Petit et al., 2004), when cows are fed increased amounts of fat or unsaturated fatty acids, which alters rumen fermentation.

Milk lactose content was increased by bST, but not until after 12 WOL, when plasma glucose concentrations had returned to prepartum concentrations, and were greater in bST-treated cows. These results are consistent with the increased hepatic gluconeogenesis that accompanies bST administration (Bauman, 1999). Although gluconeogenesis was likely enhanced soon after initiation of bST administration, this was not reflected as a bST-induced increase in circulating glucose concentrations until available glucose exceeded mammary and overall metabolic demand. These results support the concept that glucose supply, rather than overall availability of energy, limits milk yield in early lactation and likely limits the milk response to bST in early lactation (Richard et al., 1985). 
Diet did not affect plasma glucose concentrations during early lactation, but there was an interaction of diet and WOL because glucose concentrations were greater in SS cows after 8 WOL. Specific reasons for this interaction are not apparent. Indeed, in contrast to our results, others have reported no difference in plasma glucose when cows were fed diets that contained sunflower or flax seeds as 10\% of the dietary DM (Petit et al., 2004) and increased plasma glucose when cows were fed EPA and DHA from fishmeal or fish oil fatty acids (Heravi Moussavi et al., 2007).

\section{DMI and Estimated Energy and MP Balance}

Administration of bST increased milk yield but did not increase DMI. This was unexpected because increased DMI and coordinated changes in tissue metabolism usually occur to satisfy the demands of increased milk production (NRC, 1994), whether bST administration is initiated in early (Moallem et al., 2000) or late (Bauman, 1999) lactation. Others reported no increase in DMI by multiparous cows despite a bSTinduced increase in milk yield when bST treatment was initiated before peak milk yield (Moallem et al., 1997) or later in lactation (NRC, 1994). Specific reasons for these discrepancies are unclear, but several factors and their interactions affect DMI (NRC, 1994; Allen, 2000). There was no effect of diet on DMI, but both diets contained more fat and fatty acids than most typical diets for lactating cows (Allen, 2000). Although Petit et al. (2004) detected no detrimental effects of including $10 \%$ of dietary DM as whole sunflower seeds, our cows consumed more DM and our study did not include a diet without supplemental fat. Thus, we could not assess if the high-fat content of the SS and AF diets limited DMI.

Increased milk yield and lack of a corresponding increase in DMI by cows treated with bST prolonged the interval of negative EB and decreased estimated $\mathrm{EB}$ of bST-treated cows over the treatment period, but most of this effect was associated with cows fed the SS diet. As indicated by the relatively similar EB plots for SSN, $\mathrm{AFN}$, and AFY cows, most of the interaction of diet and bST was caused by the reduced EB of SSY cows. The small numerical difference in dietary $\mathrm{NE}_{\mathrm{L}}$ content had a minimal impact on overall EB because EB of the SSN and AFN cows did not differ whether EB was estimated with $\mathrm{NE}_{\mathrm{L}}$ values at $4.7 \times$ maintenance or actual DMI. The specific reason(s) for the reduced EB in SSY cows is not known.

Productive efficiency, corrected for change in BW, increased by $11.6 \%$ with bST administration and reflects a dilution of maintenance requirements because greater proportions of dietary components are captured in milk as milk yield increases (Bauman, 1999). The values obtained in this study were numerically greater than reported previously (Chalupa et al., 1996) and are likely due to a combination of greater milk yields and differences in how dietary energy content was assessed (NRC, 2001).

Circulating NEFA profiles were relatively consistent reciprocals of the estimated EB profiles, but although diet, bST, and their interaction affected EB, these factors did not influence plasma NEFA concentrations. The prolonged interval of negative EB delayed replenishment of body reserves, because BFT did not increase as quickly after the nadir in bST-treated cows. Although $\mathrm{bST}$ reduced $\mathrm{BW}$ and $\mathrm{BCS}$, differences between overall treatment means were small and comparable with previous reports (McGuffey et al., 1990). Dohoo et al. (2003) estimated that $200 \mathrm{~d}$ of bST administration reduced BCS by approximately 0.2 units, and we detected a comparable $0.25 \pm 0.09$-unit reduction. These results are consistent with the well-established effects of bST on enhanced lipolysis and reduced lipogenesis in adipose tissue when cows are in negative or positive EB, respectively (Bauman, 1999). Delayed replenishment of body reserves is consistent with the ability of bST to partition dietary nutrients and energy toward milk to better meet substrate needs of the mammary gland and supports the premise that cows treated with bST need a longer interval to replenish tissue they mobilized in early lactation. Although the expected bST-induced increase in DMI did not occur, effects of these associated alterations in tissue metabolism were detected. If the rate of increase in BW, BCS, and BFT after 28 WOL remained constant, projected BW and BCS of our cows at dry-off (320 to 390 DIM) would equal or exceed those at 1 WOL. Although projected BFT of bST-treated cows at dry-off would be less than that at 1 WOL, projected values would be similar to those at 1 WOL if the rate of increase in BFT of bST-treated cows $(0.006 \mathrm{~mm} / \mathrm{d})$ approached that of untreated cows $(0.019 \mathrm{~mm} / \mathrm{d})$ after $28 \mathrm{WOL}$.

In early lactation, estimated MPB was negative and cows had to mobilize body protein to meet requirements for milk protein synthesis. Maximum loss of body protein (based on MPB nadir) occurred before 5 WOL and estimates of MPB were positive at the same time estimates of EB were positive (11.5 $\pm 0.5 \mathrm{WOL})$. Although neither milk nor milk protein yield differed between diets, milk protein content and milk MP output were greater in cows fed SS than AF. Estimates of dietary MP intake were increased, which increased the estimated amount of total MP available to cows fed SS. A larger amount of available MP would be expected to increase the amount of AA available for absorption from the duodenum, and this should increase protein 
synthesis if AA availability were insufficient. Although NRC (2001) estimates of microbial MP for the diets were similar, negative effects of PUFA on microbial protein synthesis could have reduced the supply of AA to the mammary gland and contributed to the decreased protein content of milk from cows fed AF (enriched with DHA and EPA). This effect should be minimal because of the considerable ruminal protection (75 to 95\%; Carriquiry et al., 2008b) of PUFA in AF and because PUFA in SS were at least partially protected by the intact seed coat (Petit et al., 2004). Milk protein content was not altered by bST, but the greater yields resulted in greater milk MP output and increased MP requirements (about 5\%) when cows were treated with bST. Estimates from NRC (2001) indicate the diet supplied 47 to $51 \%$ and microbial protein supplied 42 to $46 \%$ of the MP requirement of cows in this study.

The bST-induced increase in milk yield was at least partially due to increased hepatic IGF-I production (Bauman, 1999). The typical direct association between ST and IGF-I is diminished when cows are in negative EB (Vicini et al., 1991; Bauman, 1999). Onset of this uncoupling coincides with decreased DMI before parturition and is maintained during the first few weeks of lactation when energy and nutrient intake are insufficient to meet the metabolic demands of lactation. This reduced coupling between ST and IGF-I has been proposed as a mechanism to explain the reduced response to bST in early lactation (Bauman, 1999). The IGF-I response to bST administration in this study was less rapid than the typical, almost immediate increase observed when cows are in positive or negative EB (Vicini et al., 1991; Bauman, 1999). The specific reason for the delayed IGF-I response is unclear, but is likely related to an effect of the delayed postnadir increase in $\mathrm{EB}$ on the somatotropic signaling pathway (Beauloye et al., 2002). Feeding protected saturated fat to lactating cows did not alter circulating IGF-I concentrations (Vicini et al., 1995). Although plasma IGF-I concentrations in our study were greater in cows that consumed a diet enriched with n-3 than with n-6 fatty acids, Bilby et al. (2006) detected no effect of feeding n-3 fatty acids on plasma IGF-I and Robinson et al. (2002) detected greater circulating IGF-I when lactating cows were fed n- 6 rather than n- 3 or saturated fatty acids. There was no interaction of fat source and bST on IGF-I in our study, but feeding n-3 fatty acids increased the IGF-I response to short-term administration of bST (Bilby et al., 2006). These differences might be related to differences in the overall fatty acid profile because EPA, DHA, and other PUFA can activate peroxisome proliferator-activated receptors and other nuclear receptors involved in the regulation of gene ex- pression, and the response can vary among tissue types and species (Khan and Vanden Heuvel, 2003).

\section{CONCLUSIONS}

Initiation of bST administration at 12 DIM increased milk and FCM yields and plasma IGF-I concentrations without altering the moment or magnitude of the EB nadir. Administration of bST did not alter DMI, but decreased overall EB and increased productive efficiency. Feeding a diet enriched with n-3 fatty acids decreased the impact of bST on overall EB and increased plasma IGF-I concentrations in bST-treated cows. Although $\mathrm{BW}, \mathrm{BCS}$, and BFT were reduced by bST, differences between treated and nontreated cows at the end of the study (280 DIM) were small. Because bST administration prolonged the delay in onset of tissue deposition, management options such as delayed breeding should be considered because extended lactation would provide cows with additional time to replenish their body reserves in preparation for a subsequent lactation.

\section{ACKNOWLEDGMENTS}

The authors thank Sara R. Sanders (Department of Animal Sciences, University of Arizona, Tucson) for her technical expertise and skill in performing the fatty acid analyses. We thank Monsanto Co. (St. Louis, MO) for providing the Posilac brand of recombinant bST and Alifet USA (Cincinnati, OH) for providing the Alifet-High Energy and Alifet-Repro. Excellent animal care and courteous assistance throughout the study was provided by the staff at the University of Minnesota Northwest Research and Outreach Center (Crookston, $\mathrm{MN})$.

\section{REFERENCES}

Allen, M. S. 2000. Effects of diet on short-term regulation of feed intake by lactating dairy cattle. J. Dairy Sci. 83:1598-1624.

Bauman, D. E. 1999. Bovine somatotropin and lactation: From basic science to commercial application. Domest. Anim. Endocrinol. 17:101-116.

Beauloye, V., B. Willems, V. de Coninck, S. J. Frank, M. Edery, and J. P. Thissen. 2002. Impairment of liver GH receptor signaling by fasting. Endocrinology 143:792-800.

Bilby, T. R., A. Sozzi, M. M. Lopez, F. T. Silvestre, A. D. Ealy, C. R. Staples, and W. W. Thatcher. 2006. Pregnancy, bovine somatotropin, and dietary n-3 fatty acids in lactating dairy cows: I. Ovarian, conceptus, and growth hormone-insulin-like growth factor system responses. J. Dairy Sci. 89:3360-3374.

Carriquiry, M., C. R. Dahlen, W. J. Weber, G. C. Lamb, and B. A. Crooker. 2009a. Postpartum ovarian activity in multiparous Holstein cows treated with bovine somatotropin and fed n-3 fatty acids in early lactation. J. Dairy Sci. 92:4876-4888.

Carriquiry, M., W. J. Weber, and B. A. Crooker. 2008a. Administration of bovine somatotropin in early lactation: A meta-analysis of production responses by multiparous Holstein cows. J. Dairy Sci. 91:2641-2652. 
Carriquiry, M., W. J. Weber, C. R. Dahlen, G. C. Lamb, L. H Baumgard, and B. A. Crooker. 2009b. Fatty acid composition of milk from multiparous Holstein cows treated with bovine somatotropin and fed n-3 fatty acids in early lactation. J. Dairy Sci. 92:4865-4875.

Carriquiry, M., W. J. Weber, S. C. Fahrenkrug, and B. A. Crooker. 2009c. Hepatic gene expression in multiparous Holstein cows treated with bovine somatotropin and fed $\mathrm{n}-3$ fatty acids in early lactation. J. Dairy Sci. 92:4889-4900.

Carriquiry, M., W. J. Weber, S. R. Sanders, L. H. Baumgard, and B. A. Crooker. 2008b. In vitro biohydrogenation of protected dietary fats. Anim. Feed Sci. Technol. 141:339-355.

Chalupa, W., B. Vecchiarelli, D. T. Galligan, J. D. Ferguson, L. S. Baird, R. W. Hemken, R. J. Harmon, C. G. Soderholm, D. E. Otterby, R. J. Annexstad, J. G. Linn, W. P. Hansen, F. R. Ehle, D. L. Palmquist, and R. G. Eggert. 1996. Responses of dairy cows supplemented with somatotropin during weeks 5 through 43 of lactation. J. Dairy Sci. 79:800-812.

Dohoo, I. R., K. E. Leslie, L. DesCôteaux, A. Fredeen, P. Dowling, A. Preston, and W. Shewfelt. 2003. A meta-analysis review of the effects of recombinant bovine somatotropin. 1. Methodology and effects on production. Can. J. Vet. Res. 67:241-251.

Ferguson, J. D., D. K. Beede, R. D. Shaver, C. E. Polan, J. T. Huber, and P. T. Chandler. 2000. A method to analyze production responses in dairy herds. J. Dairy Sci. 83:1530-1542.

Heravi Moussavi, A. R., R. O. Gilbert, T. R. Overton, D. E. Bauman, and W. R. Butler. 2007. Effects of feeding fish meal and n-3 fatty acids on milk yield and metabolic responses in early lactating dairy cows. J. Dairy Sci. 90:136-144.

Khan, S. A., and J. P. Vanden Heuvel. 2003. Role of nuclear receptors in the regulation of gene expression by dietary fatty acids. J. Nutr. Biochem. 14:554-567.

Lucy, M. C. 2000. Regulation of ovarian follicular growth by somatotropin and insulin-like growth factors in cattle. J. Dairy Sci. 83:1635-1647.

Lucy, M. C., and B. A. Crooker. 2001. Physiological and genetic differences between low and high index dairy cows. Pages 223-236 in Fertility in the High Producing Dairy Cow. Br. Soc. Anim. Sci. Occas. Publ. No. 26. Vol. 1. Br. Soc. Anim. Sci., Galway, Ireland.

McGuffey, R. K., H. B. Green, R. P. Basson, and T. H. Ferguson. 1990. Lactation response of dairy cows receiving bovine somatotropin via daily injections or in a sustained-release vehicle. J. Dairy Sci. 73:763-771.

Moallem, U., Y. Folman, and D. Sklan. 2000. Effects of somatotropin and dietary calcium soaps of fatty acids in early lactation on milk production, dry matter intake, and energy balance of high-yielding dairy cows. J. Dairy Sci. 83:2085-2094.

Moallem, U., M. Kaim, Y. Folman, and D. Sklan. 1997. Effect of calcium soaps of fatty acids and administration of somatotropin in early lactation on productive and reproductive performance of high producing dairy cows. J. Dairy Sci. 80:2127-2136.

NRC. 1994. Metabolic Modifiers: Effects on the Nutrient Requirements of Food-Producing Animals. Natl. Acad. Press, Washington, DC.

NRC. 2001. Nutrient Requirements of Dairy Cattle. 7th ed. Natl Acad. Press, Washington, DC.

Petit, H. V. 2003. Digestion, milk production, milk composition, and blood composition of dairy cows fed formaldehyde treated flaxseed or sunflower seed. J. Dairy Sci. 86:2637-2646.

Petit, H. V., C. Germiquet, and D. Lebel. 2004. Effect of feeding whole, unprocessed sunflower seeds and flaxseed on milk production, milk composition, and prostaglandin secretion in dairy cows. J. Dairy Sci. $87: 3889-3898$.

Richard, A. L., S. T. McCutcheon, and D. E. Bauman. 1985. Responses of dairy cows to exogenous bovine growth hormone administered during early lactation. J. Dairy Sci. 68:2385-2389.

Robinson, R. S., P. G. Pushpakumara, Z. Cheng, A. R. Peters, D. R. Abayasekara, and D. C. Wathes. 2002. Effects of polyunsaturated fatty acids on ovarian and uterine function in lactating dairy cows. Reproduction 124:119-131.

Staples, C. R., J. M. Burke, and W. W. Thatcher. 1998. Influence of supplemental fats on reproductive tissues and performance of lactating cows. J. Dairy Sci. 81:856-871.

Tyrrell, H. F., and J. T. Reid. 1965. Prediction of the energy value of cow's milk. J. Dairy Sci. 48:1215-1223.

Vicini, J. L., F. C. Buonomo, J. J. Veenhuizen, M. A. Miller, D. R. Clemmons, and R. J. Collier. 1991. Nutrient balance and stage of lactation affect responses of insulin, insulin-like growth factors I and II, and insulin-like growth factor-binding protein 2 to somatotropin administration in dairy cows. J. Nutr. 121:1656-1664.

Vicini, J. L., G. F. Hartnell, J. J. Veenhuizen, R. J. Collier, and L. Munyakazi. 1995. Effect of supplemental dietary fat or protein on the short-term milk production response to bovine somatotropin. J. Dairy Sci. 78:863-871.

Weber, W. J., C. R. Wallace, L. B. Hansen, H. Chester-Jones, and B. A. Crooker. 2007. Effects of selection for milk yield on somatotropin, insulin-like growth factor-I, and placental lactogen in Holstein cows. J. Dairy Sci. 90:3314-3325. 